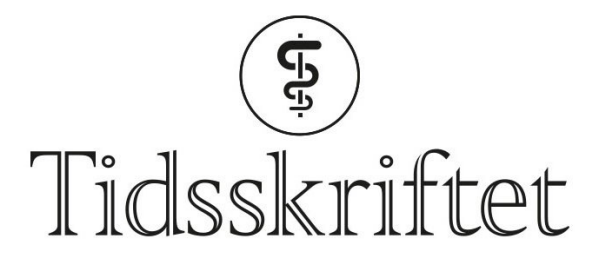

DEN NORSKE LEGEFORENING

\title{
Kan vi redde flere liv?
}

KRONIKK

\section{EWA NESS}

E-post: ewn@helsetilsynet.no

Ewa Ness er spesialist i psykiatri ved direktørens stab, Oslo universitetssykehus og Avdeling for varsler og operativt tilsyn, Statens helsetilsyn.

Forfatteren har fylt ut ICMJE-skjemaet og oppgir ingen interessekonflikter.

\section{JON RAGNAR SKOTTE}

Jon Ragnar Skotte er psykiatrisk sykepleier og seniorrådgiver ved Avdeling for varsler og operativt tilsyn, Statens helsetilsyn.

Forfatteren har fylt ut ICMJE-skjemaet og oppgir ingen interessekonflikter.

\section{TORE BUER CHRISTENSEN}

Tore Buer Christensen er spesialist i psykiatri, overlege ved Psykiatrisk avdeling, Sørlandet sykehus Arendal og seniorrådgiver ved Avdeling for varsler og operativt tilsyn, Statens helsetilsyn. Forfatteren har fylt ut ICMJE-skjemaet og oppgir ingen interessekonflikter.

\section{JAN FREDRIK ANDRESEN}

Jan Fredrik Andresen er spesialist i psykiatri og direktør i Statens helsetilsyn. Forfatteren har fylt ut ICMJE-skjemaet og oppgir ingen interessekonflikter.

Psykotisk depresjon representerer en betydelig risiko for selvmord. Vår gjennomgang av varsler etter selvmord viser at symptomer på psykotisk depresjon ofte beskrives, men er blitt oppfattet som noe annet. Det er avgjørende at denne potensielt livstruende tilstanden oppdages og behandles.

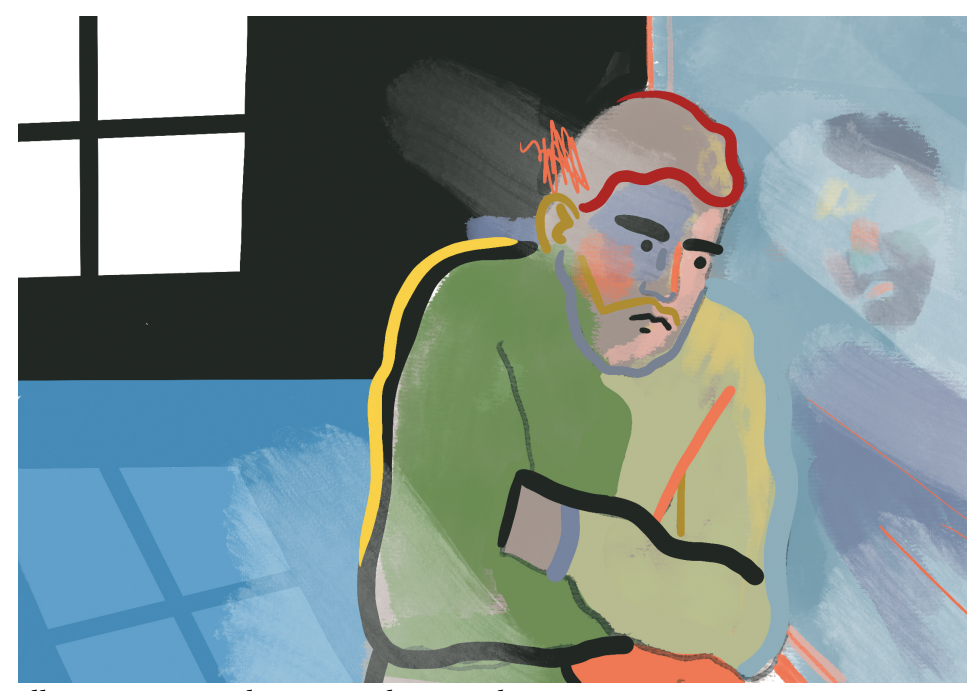


Siden varselordningen etter spesialisthelsetjenesteloven § 3-3a ble etablert i 2010, har Statens helsetilsyn mottatt og håndtert 4505 varsler. 2113 kom fra psykisk helsevern og tverrfaglig spesialisert rusbehandling, og over halvparten av disse ble avsluttet etter innledende unders $\varnothing$ kelser. De fleste varsler gjelder selvmord eller selvmordsfors $ø$ k. Det kan se ut til at det foreligger utilstrekkelig diagnostisk kompetanse på psykotisk depresjon.

Det helt grunnleggende i all helsehjelp er at pasientens tilstand og behandlingsbehov avklares så raskt som mulig. Ubehandlet alvorlig depresjon har dårlig prognose (1). Med riktig og individuelt tilpasset behandling vil imidlertid prognosen vanligvis være vesentlig bedre. I vår gjennomgang av varsler har vi funnet en rekke eksempler på at de som har kartlagt og vurdert pasientene, tilsynelatende har manglet tilstrekkelig kunnskap om psykotisk depresjon. I noen saker fant vi at så godt som alle kjernesymptomer på psykotisk depresjon var beskrevet - uten at diagnosen ble stilt. De sakene vi har undersøkt, fordeler seg jevnt på ulike helseforetak i hele landet. I de fleste sakene har pasienten vært behandlet av mange fagpersoner, inkludert psykiatere og psykologspesialister. Ofte har pasienten vært i behandling over flere uker, både poliklinisk og i døgnavdeling.

\section{Utredning og risikovurdering}

Alvorlig depresjon med psykosesymptomer er underdiagnostisert og underbehandlet (2). Grubling, angst og irritasjon kan være fremtredende, i tillegg til de vanlige symptomene som ideer om skyld, skam og somatisk sykdom. Mange ganger er det vanskelig for pasienten å snakke med andre om hvordan de har det, og de forteller ikke spontant om symptomene. Selv om disse ideene identifiseres, blir den psykotiske kvaliteten ved dem ofte ikke avdekket (3). En norsk studie har demonstrert hvordan impulsivitet hos disse pasientene utgjør en betydelig utfordring i kartlegging av selvmordsrisiko (4), idet pasienter kan handle på en psykotisk impuls med dødelig utfall.

Ofte har det vært et markant funksjonsfall og endring i væremåte i løpet av kort tid hos en person med god funksjon forut for symptomdebuten. I flere av varslene finner vi en ganske kort sykehistorie, ofte over noen få uker, uten en klar utløsende hendelse. Pasienten kan ha oppsøkt fastlegen med angst og søvnproblemer og fått forskrevet noe beroligende eller sovemedisin som ikke har hatt særlig effekt. Spesielt har vi merket oss at sterk angst og agitasjon har blitt vurdert og behandlet som en primær angstlidelse og ikke som en del av et depressivt syndrom, også etter at de har blitt henvist til spesialisthelsetjenesten. Dette gjelder særlig hos mannlige pasienter (5) som har samtidige depressive og psykotiske symptomer med stort funksjonsfall. En amerikansk undersøkelse av selvmord i døgnavdelinger og rett etter utskrivning, viste at 60 av 76 pasienter som senere tok livet sitt, hadde sterk eller ekstrem angst og eller agitasjon (6). I varsler har vi sett informasjon fra pårørende om at pasienter gikk rundt hjemme og skrek at de ikke holdt ut.

I vår gjennomgang av varsler har vi funnet en rekke eksempler på at de som har kartlagt og vurdert pasientene, tilsynelatende har manglet tilstrekkelig kunnskap om psykotisk depresjon

Psykotisk depresjon er en så alvorlig, tungtveiende risikofaktor at den alene bør tillegges stor vekt. Fra varslene ser vi at disse pasientene kan ha svart benektende på spørsmål om selvmordstanker og -planer. Dette er i tråd med funn gjort av Busch og medarbeidere (6), der $78 \%$ av pasientene som tok livet av seg, benektet selvmordstanker i den siste kommunikasjonen de hadde om dette temaet før selvmordet. I tillegg mangler disse pasientene ofte mange av de andre risikofaktorene for selvmord, som tidligere selvmordsfors $\emptyset \mathrm{k}$, rusproblemer eller relasjonsproblemer. Vi ser av journalnotatene at mange av pasientene er blitt vurdert til å ha «lav selvmordsfare».

\section{Behandlingsnivået}

Vi har erfart at mange pasienter med alvorlige depressive og psykotiske symptomer tilbys behandling poliklinisk eller ved åpen distriktspsykiatrisk døgnenhet. Vi vil argumentere 
for at en distriktspsykiatrisk poliklinikk (DPS) eller åpen døgnpost vanligvis ikke vil ha rammer til å utrede, behandle og beskytte pasienten på en forsvarlig måte i den mest alvorlige fasen, først og fremst grunnet $\varnothing \mathrm{kt}$ selvmordsfare. Retrospektivt ser vi jevnlig at pasienter som endte med å ta livet sitt, ble behandlet på et behandlingsnivå som sannsynligvis var for lavt.

Dette kan skyldes at noen av pasientene fremsto som rolige og samarbeidsvillige. Sterk angst og agitasjon kan også kamuflere de mer alvorlige underliggende psykotiske symptomene. Ofte har de gode psykososiale forhold rundt seg, og dette bidrar ytterligere til at man ikke ser dem som alvorlig syke. Det er viktig at helsepersonellet som vurderer behandlingsnivået, har kunnskap om at psykotiske symptomer ofte dekkes til ved depresjon (7).

Alvorlig depresjon med psykosesymptomer er underdiagnostisert og underbehandlet

Grad av samtykkekompetanse kan fluktuere hos disse pasientene. De blir derfor ofte innlagt frivillig med rammer som tilbyr utilstrekkelig beskyttelse mot selvmord. Noen takker også nei til tilbud om innleggelse. Det er svært bra å ha fokus på pasientens autonomi og redusert bruk av tvang, i tråd med myndighetenes føringer, men vi vil allikevel advare om risikoen for å undervurdere alvorlighetsgraden i pasientens tilstand ved psykotisk depresjon. I flere av varslene der psykotisk depresjon endte med selvmord, hadde man ikke vurdert om farekriteriet i psykisk helsevernloven var oppfylt.

\section{Parallell utredning og behandling}

I de sakene vi har sett på, er det vanligvis ikke brukt kriteriebasert diagnostikk eller skåringsverktøy. Noen av pasientene har vært i behandling i flere uker uten diagnose. Mange av pasientene er plaget med angst og søvnproblemer som de i den akutte fasen må tilbys behandling for. Å lytte til pasientens historie og å bidra til å gi håp allerede i de første møtene hører til god behandling. Et viktig mål er å redusere den tiden personen har alvorlige og plagsomme symptomer (7). Behandling av grunnlidelsen og eventuelle komorbide tilstander bør igangsettes uten opphold når tilstanden er oppdaget og tilstrekkelig utredet.

\section{Lytt til pårørende}

Pårørende er en svært viktig kilde til informasjon. Pasientene tar sjelden selv initiativ til å oppsøke helsetjenesten, de kommer oftest sammen med bekymrede pårørende. Opplysninger fra pårørende som indikerer alvorlige symptomer og funksjonsfall, bør tillegges stor vekt. Vårt inntrykk er at helsepersonell ikke i tilstrekkelig grad har lyttet til eller vektlagt informasjon fra bekymrede pårørende når de har vurdert tilsynelatende uforståelige endringer hos pasienten.

Pårørende har noen ganger heller ikke fått tilstrekkelig støtte og informasjon i en kritisk fase for familien. I noen saker har vi sett at pårørende har fått en urimelig stor belastning og mye ansvar for å ivareta og passe på pasienter med alvorlige og plagsomme symptomer som behandles hjemme. Vi vil derfor understreke at pårørendes behov for informasjon og støtte må avklares fortløpende.

Videre er det nødvendig å vurdere hvilke belastninger pårørende selv opplever at de har og ha realistiske forventninger til hva de kan bidra med. Ved mistanke om eller erkjent psykotisk depresjon vil hjemmebehandling som hovedregel ikke være tilrådelig på grunn av selvmordsfaren. Det vil av den grunn være viktig å sette familien i stand til å ta gode beslutninger på egne vegne. Både pasient og nærmeste pårørende må gis tilpasset informasjon om den aktuelle tilstanden og risikoen forbundet med denne, herunder informasjon om selvmordsrisiko og hva slags behandling man anbefaler i de ulike stadiene av forløpet (8). 


\section{Gjennomgang av alvorlige hendelser}

Det er avgjørende at helsepersonell har kompetanse til å oppdage, diagnostisere og behandle denne tilstanden. Rask iverksetting av god, kunnskapsbasert behandling kan være livreddende (8). Det er virksomhetenes ansvar å sikre at helsepersonell har nødvendig kompetanse i forebygging av selvmord, behandling av psykotisk depresjon og identifikasjon av realitetsbrist. Psykotisk depresjon forekommer ikke ofte, og det er derfor vanskelig for klinikere å få mengdetrening. Medisinsk simulering, deling av kliniske erfaringer og gjennomgang av kasuistikker er eksempler på metoder som kan bidra til å sikre nødvendig tverrfaglig kompetanse. Virksomhetene må videre etablere tilstrekkelige rammebetingelser, slik at pasienter med symptomer på psykotisk depresjon kan bli fanget opp så raskt som mulig og gitt forsvarlig behandling.

Opplysninger fra pårørende som indikerer alvorlige symptomer og funksjonsfall, bør tillegges stor vekt

Virksomhetene har ansvar for at alle selvmord eller alvorlige selvmordsfors $ø \mathrm{k}$ blir systematisk gjennomgått i etterkant, med tanke på læring og forbedring. Dette er forankret i forskrift om ledelse og kvalitetsforbedring i helse- og omsorgstjenesten $\S 8 \mathrm{e}(9)$, men kjennetegner også god faglig ledelse. Statens helsetilsyn har utarbeidet en mal for egenvurdering som vi har bedt helseforetak om å gjennomføre etter at vi har vurdert varselet (10). Hensikten er å få ledere og helsepersonell til sammen å reflektere over egen praksis for å identifisere hva som gikk galt: Fanget man opp symptomene, hvordan vurderte man dem og hvilken konsekvens fikk vurderingene for behandlingen? Finnes det tilstrekkelig opplæring og kompetanse hos de ansatte? Finnes det rutiner for spesialistvurdering?

\section{Avslutning}

I et pasientsikkerhetsperspektiv bør man kartlegge og analysere hele behandlingen, hvert enkelt trinn, for å identifisere mulighet for svikt og forbedring. Erfaringsmessig svikter det ofte på flere punkter når det skjer alvorlige hendelser. I andre risikoutsatte sektorer, som luftfart og oljeindustrien, har man et systemperspektiv når man skal lære av alvorlige hendelser.

For å unngå urealistiske forventninger om at alle selvmord kan forhindres, er det samtidig viktig å erkjenne at pasienter som behandles i psykisk helsevern, vil kunne ta livet sitt uten at dette alltid skyldes svikt $\mathrm{i}$ helsetjenesten.

\section{LITTERATUR:}

1. Bramness JG, Walby FA, Tverdal A. The sales of antidepressants and suicide rates in Norway and its counties 1980-2004. J Affect Disord 2007; 102:1-9. [PubMed][CrossRef]

2. Rothschild AJ. Challenges in the treatment of depression with psychotic features. Biol Psychiatry 2003; 53: 680-90. [PubMed][CrossRef]

3. Rothschild AJ, Winer J, Flint AJ et al. Missed diagnosis of psychotic depression at 4 academic medical centers. J Clin Psychiatry 2008; 69: 1293-6. [PubMed][CrossRef]

4. Fredriksen KJ, Schoeyen HK, Johannessen JO et al. Psychotic depression and suicidal behavior. Psychiatry 2017; 80: 17-29. [PubMed][CrossRef]

5. Wålinder J, Rutzt W. Male depression and suicide. Int Clin Psychopharmacol 2001; 16 (suppl 2): S21-4. [PubMed][CrossRef]

6. Busch KA, Fawcett J, Jacobs DG. Clinical correlates of inpatient suicide. J Clin Psychiatry 2003; 64: 14-9. [PubMed][CrossRef]

7. Mork E, Mehlum L, Walby FA. Selvmord ved depresjon med psykotiske symptomer og bipolar lidelse: forekomst, risikofaktorer og nevrobiologiske forhold. J Suicidologi 2015; 14. doi: 
10.5617/suicidologi.1986. [CrossRef]

8. Nasjonale retningslinjer for diagnostisering og behandling av voksne med depresjon i primær-og spesialisthelsetjenesten. IS-1561. Oslo: Helsedirektoratet, 2009.

https://www.helsedirektoratet.no/retningslinjer/voksne-med-depresjon/Voksne\%2omed\%2odepresjon \%20\%E2\%80\%93\%20Nasjonal\%2oretningslinje\%2ofor\%2odiagnostisering\%2oog\%2obehandling\%20\%20i\% 2oprim\%C3\%A6r-\%20og\%2ospesialisthelsetjenesten.pdf/_/attachment/inline/edod2ef2-

da11-4c4e-9423-58e1b6ddc4d9:961cda6577d48345aaod6fe9642b6b6acc2a6506/Voksne\%2omed\%2odepre sjon\%20\%E2\%80\%93\%2oNasjonal\%2oretningslinje\%2ofor\%2odiagnostisering\%20og\%2obehandling\%20\%2 oi\%2oprim\%C3\%A6r-\%20og\%2ospesialisthelsetjenesten.pdf Lest 12.2.2020.

9. FOR-2016-10-28-1250. Forskrift om ledelse og kvalitetsforbedring i helse- og omsorgstjenesten. https://lovdata.no/dokument/SF/forskrift/2016-10-28-1250 Lest 29.4.2020.

10. Informasjonsskriv for varsling av hendelser innen psykisk helsevern og tverrfaglig spesialisert rusbehandling etter spesialisthelsetjenesteloven §3-3a. Oslo: Statens Helsetilsyn, 2018.

https://www.med.uio.no/klinmed/forskning/sentre/nssf/kartleggingssystemet/dokumenter/formalia/i nfoskriv-til-spesialisthelsetjenesten.pd.pdf Lest 12.2.2020.

Publisert: 18. mai 2020. Tidsskr Nor Legeforen. DOI: 10.4045/tidsskr.19.0804

Mottatt 11.12.2019, første revisjon innsendt 21.1.2020, godkjent 12.2.2020.

(C) Tidsskrift for Den norske legeforening 2020. Lastet ned fra tidsskriftet.no 